\section{(C) OPEN ACCESS}

\title{
Risk category system to identify pituitary adenoma patients with AlP mutations
}

\author{
Francisca Caimari, ${ }^{1,2}$ Laura Cristina Hernández-Ramírez, ${ }^{1,3}$ Mary N Dang, ${ }^{1}$ \\ Plamena Gabrovska, ${ }^{1}$ Donato lacovazzo, ${ }^{1}$ Karen Stals, ${ }^{4}$ Sian Ellard, ${ }^{4}$ Márta Korbonits, \\ on behalf of The International FIPA consortium
}

\begin{abstract}
- Additional material is published online only. To view please visit the journal online (http://dx.doi.org/10.1136/ jmedgenet-2017-104957).

${ }^{1}$ Centre of Endocrinology, William Harvey Research Institute, Barts and the London School of Medicine and Dentistry, Queen Mary University of London, London, UK

2Department of Endocrinology, Universitat Autònoma de Barcelona (UAB), Barcelona, Spain

${ }^{3}$ Section of Endocrinology and Genetics, Eunice Kennedy Shriver National Institute of Child Health and Human Development (NICHD), National Institutes of Health (NIH), Bethesda, Maryland, USA ${ }^{4}$ Department of Molecular Genetics, Royal Devon and Exeter NHS Foundation Trust, Exeter, UK
\end{abstract}

Correspondence to Professor Márta Korbonits, Centre of Endocrinology, William Harvey Research Institute, Barts and The London School of Medicine, Queen Mary University of London, London EC1M 6BQ, UK; m.korbonits@ qmul.ac.uk

Received 30 July 2017 Revised 19 November 2017 Accepted 21 November 2017 Published Online First 10 February 2018

\section{ABSTRACT \\ Background Predictive tools to identify patients at risk for gene mutations related to pituitary adenomas are very helpful in clinical practice. We therefore aimed to develop and validate a reliable risk category system for aryl hydrocarbon receptor-interacting protein (AIP) mutations in patients with pituitary adenomas.}

Methods An international cohort of 2227 subjects were consecutively recruited between 2007 and 2016, including patients with pituitary adenomas (familial and sporadic) and their relatives. All probands $(n=1429)$ were screened for AIP mutations, and those diagnosed with a pituitary adenoma prospectively, as part of their clinical screening $(n=24)$, were excluded from the analysis. Univariate analysis was performed comparing patients with and without AIP mutations. Based on a multivariate logistic regression model, six potential factors were identified for the development of a risk category system, classifying the individual risk into low-risk, moderate-risk and high-risk categories. An internal cross-validation test was used to validate the system.

Results 1405 patients had a pituitary tumour, of which $43 \%$ had a positive family history, $55.5 \%$ had somatotrophinomas and $81.5 \%$ presented with macroadenoma. Overall, 134 patients had an AIP mutation (9.5\%). We identified four independent predictors for the presence of an AIP mutation: age of onset providing an odds ratio (OR) of 14.34 for age 0-18 years, family history (OR 10.85), growth hormone excess (OR 9.74) and large tumour size (OR 4.49). In our cohort, $71 \%$ of patients were identified as low risk ( $<5 \%$ risk of AIP mutation), $9.2 \%$ as moderate risk and $20 \%$ as high risk ( $\geq 20 \%$ risk). Excellent discrimination (c-statistic $=0.87$ ) and internal validation were achieved. Conclusion We propose a user-friendly risk categorisation system that can reliably group patients into high-risk, moderate-risk and low-risk groups for the presence of AIP mutations, thus providing guidance in identifying patients at high risk of carrying an AIP mutation. This risk score is based on a cohort with high prevalence of AIP mutations and should be applied cautiously in other populations.

\section{INTRODUCTION}

Pituitary adenomas are relatively common lesions, present in approximately $17 \%$ of the general population, ${ }^{1}$ although clinically relevant disease is identified in only around 1:1000 subjects. ${ }^{2}{ }^{3}$ Most pituitary adenomas are sporadic; however, familial cases are increasingly recognised, representing some $5 \%$ of all patients presenting with pituitary adenomas. ${ }^{4}$ Mutations in the aryl hydrocarbon receptor-interacting protein $(A I P)$ gene predispose to the development of pituitary adenomas but with a low penetrance $(20 \%-23 \%) .^{5-8}$ AIP mutations can be identified either in the context of familial isolated pituitary adenomas (FIPA), defined by the presence of pituitary adenomas in two or more family members with no other syndromic features, or as simplex cases with a germline mutation but no known family history of the disease. The prevalence of AIP mutations is around $20 \%$ in FIPA kindreds, ${ }^{78}$ while in sporadic pituitary adenomas, the prevalence ranges between $3.6 \%$ and 20\%, ${ }^{9}{ }^{10}$ depending on the age group studied.

More than 100 different 'pathogenic' or 'likely pathogenic"11 germline AIP variants have been described (non-sense, missense, in frame deletion/ insertion, segmental duplication, large genomic deletion, frameshift, promoter, start codon and splice-site mutations ${ }^{8}$ ), while several variants are currently considered as having 'unknown significance'. ${ }^{12}$

Although all types of pituitary adenomas have been described with germline AIP mutations, patients with such mutations typically have young-onset growth hormone $(\mathrm{GH})$-secreting or $\mathrm{GH}$-secreting and prolactin-secreting tumours with generally poor responsivity to conventional treatment, and aggressive behaviour compared with those with no recognised mutation, ${ }^{78}$ often requiring repeated surgery and radiotherapy and therefore needing close surveillance. ${ }^{713} 14$

Risk assessment for an AIP mutation has important clinical implications, and the genetic screening of family members allows for the identification of those at risk of developing aggressive pituitary adenomas. ${ }^{8} 1516$ Early diagnosis at a non-invasive stage can potentially lead to a higher chance of effective or curative treatment. ${ }^{8} 15$

There are no formal guidelines defining the criteria for genetic screening pituitary adenoma patients for AIP mutations, and currently the clinical decision for screening is based on expert recommendation. ${ }^{16}{ }^{17}$ Identification of AIP mutation-positive patients can lead to the detection of carriers with otherwise unrecognised disease, ${ }^{8} 15$ potentially leading to a better prognosis. Our study aimed to develop and validate a risk category system to stratify patients with isolated pituitary adenomas for their risk of carrying AIP mutations. This risk 
category system was designed to serve as an effective tool to aid clinical decision making and the identification of AIP mutation carriers in clinical practice.

\section{MATERIALS AND METHODS}

Two thousand two hundred and twenty-seven subjects were included in our database from February 2007 to June 2016, including 1429 affected subjects with pituitary tumours and 798 unaffected relatives. Subjects were recruited via the FIPA consortium, an international research group. The data collected from medical records related to each individual patient were sent to our group, and the information was checked to confirm that all patients met the inclusion criteria. All subjects included signed the informed consent approved by the local ethics committee.

We included patients who presented with FIPA and patients diagnosed with apparently sporadic pituitary adenomas with disease onset at $\leq 30$ years of age. In addition, we also included referred patients with sporadic adenomas and an age of onset $>30$ years. Patients with X-linked acrogigantism syndrome $(\mathrm{XLAG})^{18} 19$ and patients who presented with other recognised syndromes such as multiple endocrine neoplasia type 1 or type 4, Carney complex and DICER 1 syndrome, were excluded. ${ }^{20}$ These conditions were excluded on the basis of clinical, biochemical and, in some cases, genetic testing, as appropriate. Although patients with XLAG also belong to the FIPA group, their clinical characteristics are so distinct that we felt that they should not be included in this risk prediction analysis. Patients diagnosed prospectively as a result of familial screening of known AIP mutations were also excluded from the analysis. Genetic screening for AIP mutations was performed using Sanger sequencing and multiplex ligation-dependent probe amplification, as previously described. ${ }^{8}$ Genomic DNA was obtained from blood or saliva samples. The pathogenicity of the detected variants was assessed using the Mutation Taster (http://www.mutationtaster.org/), Anovar ${ }^{21}$ and Variant Effect Predictor (VEP $)^{22}$ in silico prediction programmes. We also included published clinical and experimental data on the previously reported variants. Only pathogenic or likely pathogenic variants were considered as mutations. ${ }^{11}$

\section{Definition of variables}

Patients were identified as affected if they had either (1) a pituitary tumour or (2) pituitary hyperplasia associated with hormone hypersecretion. FIPA was defined by the presence of pituitary adenomas in two or more members of a family with no other associated clinical features. The family history included assessment of all known 'blood relatives'. The diagnoses were categorised as GH excess (including acromegaly and gigantism, with or without prolactin cosecretion), non-functioning pituitary adenoma (NFPA), prolactinoma, Cushing's disease and other diagnoses (any other type of functioning pituitary tumour). Macroadenomas were defined by tumour size $\geq 10 \mathrm{~mm}$. Age of onset was defined as the age at presentation of the first symptom. Pituitary apoplexy was defined by a clinical history of haemorrhage and/or infarction of a pituitary adenoma.

\section{Statistical analysis}

The Shapiro-Wilks test was used to assess Gaussian distribution for continuous variables. Normally distributed variables were expressed as mean and SD and were analysed with the Student's t-test. Median and IQR were used to describe non-normally distributed variables. These variables were analysed with the Mann-Whitney U test. Qualitative variables were expressed as percentage and analysed with the $\chi^{2}$ test to compare two or more groups; $\mathrm{P}<0.05$ was taken as significant.

The following clinically relevant variables were included to generate the model: family history of pituitary tumours, gender, age of onset (categorised as $\leq 18$ years, 19-30 years and $>30$ years old), adenoma type (categorised as tumours secreting $\mathrm{GH}$ vs others), adenoma size (categorised as macroadenoma vs microadenoma or hyperplasia) and history of pituitary apoplexy. Interactions between all the studied variables were assessed with the likelihood ratio test. Variable selection was carried out through all possible equations methods, where every potential combination of the independent variables were computed and subsequently evaluated to assess the performance of the possible models. ${ }^{23}$ We selected the final model based on the Akaike information criteria, area under the receiver operating characteristic (ROC) curve and the Hosmer-Lemeshow tests. A logistic regression with the selected variables was performed, and results were expressed with an odds ratio (OR) and its 95\% confidence interval (CI).

We arbitrarily categorised the risk of AIP mutation into low-risk (<5\%), moderate-risk (5\%-19\%) and high-risk $(\geq 20 \%)$ groups. Discrimination of the model was assessed with the c-statistic, and its calibration was assessed comparing observed versus model-derived AIP mutation risk and with the Hosmer-Lemeshow test. Finally, we assessed internal validity with a cross-validation procedure for a realistic estimation of the performance of the prediction model. Performance measures included $R^{2}$ (explained variation of the model). Considering the size of our cohort, we randomly divided the sample in five equalsized parts, and we calculated the difference between our model and the resampling average. STATA software V.13.1 was used for statistical analysis.

\section{RESULTS}

Out of the 1429 pituitary adenoma patients, 153 carried an AIP mutation (10.7\%). Out of the 343 relatives of patients with AIP mutations, 165 were carriers of an AIP mutation (48.1\%). The clinical characteristics of the whole cohort are detailed in table 1.

Twenty-four family members were prospectively diagnosed with a pituitary adenoma, 19 of these carried an AIP mutation (clinical characteristics are included in online supplementary table 1), while five belonged to AIP mutation-negative

\begin{tabular}{|c|c|}
\hline Clinical characteristic & $\mathrm{n}=1405^{*}$ \\
\hline AIP mutation, $\mathrm{n}(\%)$ & $134(9.5)$ \\
\hline Familial, n (\%) & $607(43.2)$ \\
\hline Gender, $\mathrm{n}$ (\% male) & $680(48.5)$ \\
\hline \multicolumn{2}{|l|}{ Diagnosis, n (\%) } \\
\hline GH excess & $767(55.5)$ \\
\hline NFPA & $185(13.4)$ \\
\hline Prolactinoma & $344(24.9)$ \\
\hline Cushing's disease & $74(5.4)$ \\
\hline Other diagnosis & $11(0.8)$ \\
\hline Age of onset (years) & $27.1 \pm 13.1$ \\
\hline Age at diagnosis (years) & $30.8 \pm 13.4$ \\
\hline Macroadenoma, n (\%) & $977(81.5)$ \\
\hline Extrasellar extension, $\mathrm{n}(\%)$ & $446(60.1)$ \\
\hline Pituitary apoplexy, n (\%) & $48(3.9)$ \\
\hline
\end{tabular}


Table 2 Novel AIP mutations not previously reported. gnomAD: http://gnomad.broadinstitute.org/

\begin{tabular}{|c|c|c|c|c|c|c|c|c|c|}
\hline AIP mutation & MAF in gnomAD & Variant type & $\begin{array}{l}\text { In silico } \\
\text { prediction* }\end{array}$ & Probability score $t$ & Gender & $\begin{array}{l}\text { Familial versus } \\
\text { simplex }\end{array}$ & Diagnosisł & $\begin{array}{l}\text { Age at } \\
\text { diagnosis }\end{array}$ & $\begin{array}{l}\text { Age at } \\
\text { onset }\end{array}$ \\
\hline $\begin{array}{l}\text { c.240_241delinsTG } \\
\text { (p.M80_R81delinsIG) }\end{array}$ & Not reported & $\begin{array}{l}\text { Insertion } \\
\text { deletion }\end{array}$ & High & Disease causing 1 & M & Simplex & Gigantism & 8 & 5 \\
\hline $\begin{array}{l}\text { c.333delC } \\
\left(p . K 112 \text { Rfs }^{*} 44\right)\end{array}$ & Not reported & Frameshift & High & Disease causing 1 & $\mathrm{~F}$ & Simplex & Gigantism & 9 & 7 \\
\hline $\begin{array}{l}\text { c.376_377delCA } \\
\text { (p.Q126Dfs*3) }\end{array}$ & Not reported & Frameshift & High & Disease causing 1 & $\mathrm{~F}$ & Simplex & Gigantism & 13 & 10 \\
\hline $\begin{array}{l}\text { c. } 605 A>G \\
\text { (p.Y202C) § }\end{array}$ & Not reported & Missense & High & Disease causing 0.99 & M & Simplex & Gigantism & 10 & 10 \\
\hline $\begin{array}{l}\text { c. } 645+1 G>C \\
\text { (p.?) }\end{array}$ & Not reported & Splicing & High & Disease causing 1 & M & Simplex & Acromegaly & 33 & 24 \\
\hline $\begin{array}{l}\text { c.991T>C } \\
\text { (p.331Rext91) }\end{array}$ & Not reported & Missense & High & Polymorphism 0.99 & M & Simplex & Gigantism & 16 & 12 \\
\hline
\end{tabular}

*In silico prediction of probability of damaging mutation by Variant Effect Predictor and Anovar.

†Probability of pathogenic mutation by Mutation Taster.

$\ddagger$ All patients had macroadenoma, and none of them presented with pituitary apoplexy.

$\S$ This missense variant affects position 22 in the first tetratricopeptide domain of AIP, a well-conserved position in various tetratricopeptide domain proteins. ${ }^{32} 38$

AIP, aryl hydrocarbon receptor-interacting protein; MAF, minor allele frequency.

families. Prospectively diagnosed patients were excluded from the analysis.

Six novel AIP mutations were found in one patient each, their characteristics are detailed in table 2. All AIP mutations identified are listed in online supplementary table 2.

The age of onset was significantly lower in AIP-positive versus $A I P$-negative patients (16 (14-24) (IQR) vs 25 (19-33) years, $\mathrm{P}<0.001)$, as was the age at diagnosis $(21(16-31)$ vs 29 $(22-38)$ years, $\mathrm{P}<0.001)$. Table 3 contains the comparison of clinical characteristics of $A I P$ mutation-positive and AIP-negative patients.

The likelihood ratio test to evaluate interaction terms was non-significant $(\mathrm{P}=0.149)$, hence interaction terms were

Table 3 Clinical characteristics comparing AIP-positive and AIPnegative patients

\begin{tabular}{lccr}
\hline Clinical characteristic & AIP positive & AIP negative & P value \\
\hline Familial, $\mathrm{n}(\%)$ & $89(66.4)$ & $518(40.8)$ & $<0.001$ \\
\hline Gender, $\mathrm{n}(\%$ male) & $83(61.9)$ & $597(47.1)$ & 0.001 \\
\hline Diagnosis, $\mathrm{n}(\%)$ & & & $<0.001$ \\
$\quad$ GH excess & $119(88.8)$ & $648(52)$ & \\
NFPA & $4(3)$ & $181(14.5)$ & \\
Prolactinoma & $11(8.2)$ & $333(26.7)$ & \\
Cushing's disease & 0 & $74(5.9)$ & \\
Other diagnosis & 0 & $11(0.9)$ & \\
Age of onset (years and percentages) & & $<0.001$ \\
0-18 & $79(60.3)$ & $259(23.6)$ & \\
19-30 & $33(25.2)$ & $506(46)$ & \\
$>30$ & $19(14.5)$ & $336(30.5)$ & \\
Age at diagnosis (years and percentages) & & $<0.001$ \\
0-18 & $53(40.5)$ & $163(14.1)$ & \\
19-30 & $44(33.6)$ & $497(43)$ & \\
$>30$ & $34(26)$ & $495(42.9)$ & \\
\hline Maximum diameter (mm) ${ }^{*}$ & $16(10.7-25)$ & $20(11-30)$ & 0.518 \\
\hline Macroadenoma, $\mathrm{n}(\%)$ & $112(93.3)$ & $865(80.2)$ & $<0.001$ \\
\hline Extrasellar extension, $\mathrm{n}(\%)$ & $52(81.3)$ & $394(58.1)$ & $<0.001$ \\
\hline Pituitary apoplexy, $\mathrm{n}(\%)$ & $12(9.5)$ & $36(3.3)$ & 0.001 \\
\hline Number of treatments* & $2(1-3)$ & $1(1-2)$ & 0.055 \\
\hline * & &
\end{tabular}

*Median and IQR

NFPA, non-functioning pituitary adenoma. excluded from the model. The variable selection process suggested that pituitary apoplexy and gender should be removed from the model, as they did not add predictive power. A markedly increased risk of an AIP mutation was associated with having a family history, a GH-excess adenoma, macroadenomas and young age of onset. The variables included in the predictive model are listed in table 4 in the order of their statistical strength for prediction. Good discriminative power was achieved with the area under the curve (AUC), reaching a value of 0.87 (95\% CI 0.84 to 0.90 ) (figure 1 ). We stratified the risk of having an AIP mutation into low risk (<5\%), moderate risk (5\%-19\%) and high risk ( $\geq 20 \%$ ), based on our predictive model. Figure 2 shows stratified risks according to age, family history, tumour type and tumour size. In our cohort, enriched with familial, GH-secreting adenomas and young-onset cases, $70.8 \%$ of patients were identified as low risk, 9.2\% as intermediate risk, while $20 \%$ were at high risk (risk $\geq 20 \%$ ). Calibration results, comparing observed and model-predicted AIP mutation risk across the three risk groups, are depicted in the online supplementary figure 1. The Hosmer-Lemeshow test was non-significant $(\mathrm{P}=0.213)$, suggesting that the model is well calibrated.

Finally, the model showed good internal validation, as tested by the cross-validation technique, as the $\mathrm{R}^{2}$ shrinkage was $<10 \%$ in absolute terms (from 0.294 to 0.223 ).

Table 4 Logistic regression to generate a predictive model for AIP mutations*

\begin{tabular}{lcc}
\hline Variable & OR $(95 \% \mathrm{Cl})$ & P value \\
\hline Age of onset & & \\
\hline 30 & 1 & - \\
$0-18$ & $14.34(7.41$ to 29.31$)$ & $<0.001$ \\
\hline $19-30$ & $2.26(1.17$ to 4.35$)$ & 0.015 \\
\hline Positive family history & $10.85(6.48$ to 18.16$)$ & $<0.001$ \\
\hline Diagnosis & & \\
\hline Others & 1 & - \\
\hline GH excess & $9.74(5.12$ to 18.52$)$ & $<0.001$ \\
\hline Size (macroadenoma) & $4.49(1.91$ to 10.59$)$ & 0.001 \\
\hline
\end{tabular}

*Variables are listed in the order of their statistical strength for prediction and each $\mathrm{OR}$ is adjusted for all the other variables.

AIP, aryl hydrocarbon receptor-interacting protein; $\mathrm{GH}$, growth hormone. 


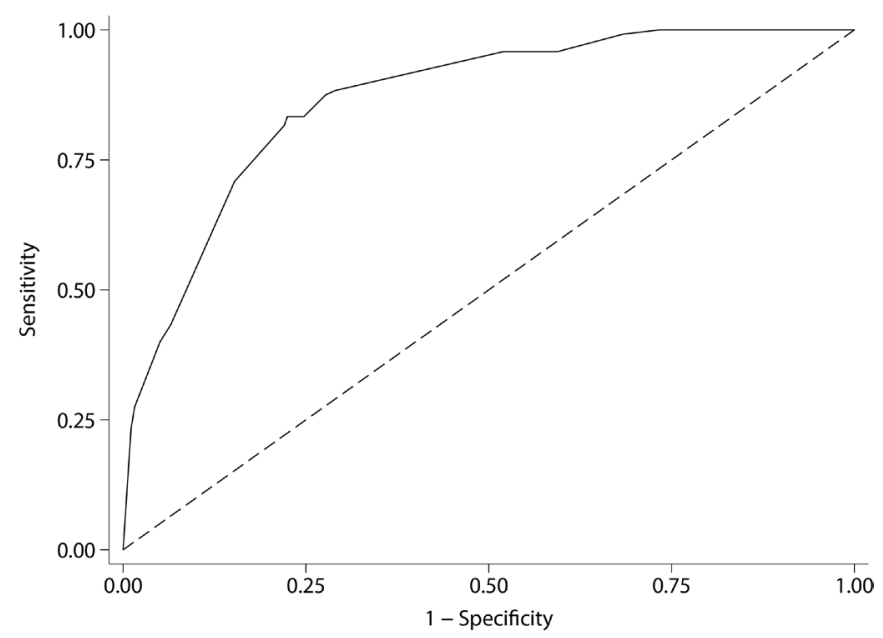

Figure 1 Area under the receiver operating characteristic curve of the AIP mutation risk category system is 0.87 (95\% Cl 0.84 to 0.90 ), indicating an excellent discriminating power.

\section{Age of onset $\leq 18$}

\begin{tabular}{|c|c|c|c|c|c|}
\hline \multicolumn{2}{|c|}{ Familial } & \multicolumn{3}{c|}{ Simplex } \\
\cline { 2 - 3 } \multicolumn{1}{|c|}{ GH excess } & & \multicolumn{2}{c|}{ GH excess } \\
\cline { 2 - 3 } \cline { 5 - 5 } & No & Yes & & No & Yes \\
\cline { 2 - 5 } \cline { 4 - 5 } Macro & $25 \%$ & $76 \%$ & Macro & $3 \%$ & $23 \%$ \\
\hline Micro & $7 \%$ & $42 \%$ & Micro & $1 \%$ & $6 \%$ \\
\hline
\end{tabular}

Age of onset 19-30

\begin{tabular}{|c|c|c|c|c|c|}
\hline \multicolumn{3}{c|}{ Familial } & \multicolumn{3}{c}{ Simplex } \\
\cline { 2 - 3 } \cline { 5 - 6 } \multicolumn{1}{c|}{ GH excess } & & \multicolumn{2}{c|}{ GH excess } \\
\cline { 2 - 5 } \cline { 5 - 6 } & No & Yes & & No & Yes \\
\hline Macro & $5 \%$ & $34 \%$ & Macro & $1 \%$ & $4 \%$ \\
\hline Micro & $1 \%$ & $10 \%$ & Micro & $<1 \%$ & $1 \%$ \\
\hline
\end{tabular}

Age of onset $\geq 31$

\begin{tabular}{|c|c|c|c|c|c|}
\hline \multicolumn{3}{|c|}{ Familial } & \multicolumn{3}{|c|}{ Simplex } \\
\hline & \multicolumn{2}{|c|}{ GH excess } & & \multicolumn{2}{|c|}{ GH excess } \\
\hline & No & Yes & & No & Yes \\
\hline Macro & $2 \%$ & $18 \%$ & Macro & $<1 \%$ & $2 \%$ \\
\hline Micro & $1 \%$ & $5 \%$ & Micro & $<1 \%$ & $1 \%$ \\
\hline
\end{tabular}

Figure 2 Risk stratification for AIP mutations, classified as low risk $(<5 \%)$, moderate risk $(5 \%-19 \%)$ or high risk $(\geq 20 \%)$. Red: risk of AIP mutation $\geq 20 \%$; orange: risk of AIP mutation between $5 \%$ and $19 \%$; green: risk of AIP mutation $<5 \%$. GH, growth hormone; macro, macroadenoma; micro, microadenoma; simplex, patients with no known family history.

\section{DISCUSSION}

Using state-of-the-art statistical methods applied to a large cohort of patients, we have identified four significant predictors for the presence of carrying an AIP mutation, and these are immediately accessible for routine clinical practice. Our data suggest that a positive family history, young age of onset, somatotroph tumour type and large tumour size can predict the risk of an AIP mutation according to our risk model, which has been validated in a large series of patients. Once a mutation carrier is identified, genetic testing can be performed for family members. The overall risk category of a kindred should be based on the risk score of the family member with the highest risk.

Despite the increasing number of genes associated with FIPA, ${ }^{5} 18$ formal guidelines do not currently include recommendations for screening for AIP mutations, ${ }^{24} 25$ and therefore such screening is usually performed on the basis of expert recommendations. ${ }^{16} 172627$ These recommendations include patients who have (1) a family history of pituitary adenoma, (2) childhood-onset pituitary adenoma or (3) a pituitary somatotroph or lactotroph macroadenoma diagnosed before the age of 30 years; however, no data stratifying the different risks between these groups have been provided. $^{9101617}$ Here we provide risk stratification for AIP mutation positive patients, using a combination of clinical variables, all of which should be easily available at the time of diagnosis.

Not surprisingly, all the variables included in our AIP risk category system have been repeatedly reported as typical clinical features of AIP mutation-positive patients. The age of disease onset is the strongest predictive factor, with a maximum risk for an AIP mutation present in those patients who presented with an adenoma during childhood (OR 14.3 (95\% CI 7.4 to 27.7), $\mathrm{P}<0.001)$. This result was expected, as the prevalence of $A I P$ mutations in paediatric cases has been reported to be between 6\% and 23\%. ${ }^{9102829}$ An age between 19 and 30 years (OR 2.3 (95\% CI 1.2 to 4.4 ), $\mathrm{P}=0.015$ ) is also a strong predictor. In a previous study, among subjects with sporadic macroadenomas diagnosed before the age of 30 years, an AIP mutation was found in $11.7 \%$ overall, with a positive finding in $13.3 \%$ of patients with somatotrophinomas, $11.5 \%$ of those with prolactinomas and $6.3 \%$ of those with NFPAs. ${ }^{28}$ Taking the historical $10 \%$ risk cut-off for genetic screening, ${ }^{30}$ patients with familial $\mathrm{GH}$-secreting macrodenoma, $\leq 30$-year-old patients with familial GH-secreting microadenomas and sporadic childhood-onset GH-secreting macroadenomas are all above this threshold.

The second strongest predictive variable was positive family history of pituitary adenomas (OR 10.85 (95\% CI 6.48 to 18.16), $\mathrm{P}<0.001)$. Although the majority of FIPA families have not yet had the causative gene identified, the largest available cohorts found that about 20\% of FIPA kindreds harbour a heterozygous germline mutation in the AIP gene, ${ }^{78}$ with the overall rate being slightly higher in homogeneous versus heterogeneous kindreds $\left(22.8 \%\right.$ and $16.7 \%$, respectively). ${ }^{16}$

$\mathrm{GH}$ excess is also a good independent predictor for AIP mutations in our model (OR 9.74 (95\% CI 5.12 to 18.52), $\mathrm{P}<0.001$ ). One of the most important characteristics of patients with AIP mutations is the predominance of somatotrophinomas or somatolactotrophinomas, which account for around $80 \%$ of the cases. Prolactinomas and clinically NFPAs with positive GH and/ or PRL immunostaining are also well described, while ACTH-secreting or TSH-secreting adenomas or gonadotrophin positive or null cell NFPAs are very rare. ${ }^{31}$

In addition, we demonstrate that patients with macroadenomas have more than four times the risk of harbouring an AIP mutation compared with those with microadenomas (OR 


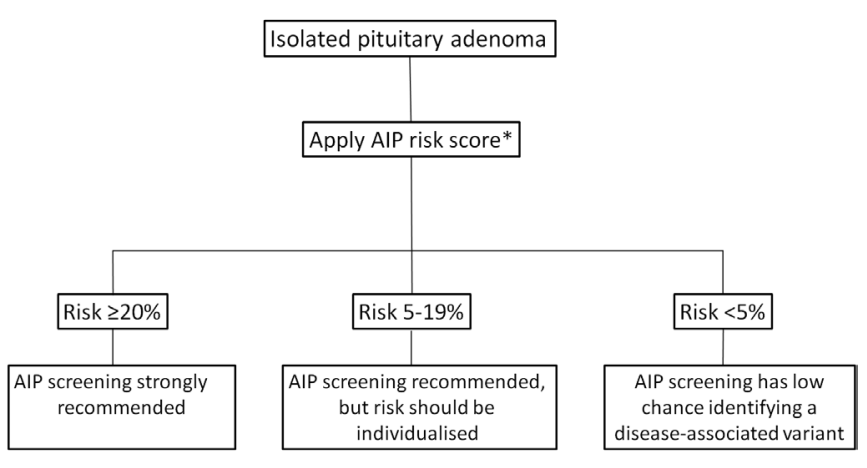

Figure 3 AIP screening algorithm based on the proposed risk category system. The overall risk category of a kindred should be based on the risk score of the family member with the highest risk. AIP, aryl hydrocarbon receptor-interacting protein. ${ }^{*}$ See figure 2 .

4.49 (95\% CI 1.91 to 10.59$), \mathrm{P}=0.001)$. Patients with AIP mutations have macroadenomas in up to $90 \%$ of the cases, and their tumours are significantly larger and more frequently show an extrasellar extension compared with non-mutated familial ${ }^{8}$ and sporadic cases. ${ }^{6-8}$ Cases of double adenomas have also been described among AIP mutation positive patients, ${ }^{32}$ while pituitary hyperplasia associated with GH excess ${ }^{33} 34$ is rare.

We also evaluated other clinical characteristics as possible predictors of AIP mutations. For instance, AIP mutation-positive patients frequently have a history of pituitary apoplexy, which is often the presenting feature. ${ }^{833}$ It is unclear whether this is due to the fact that these tumours are large and rapidly growing adenomas or whether an additional molecular mechanism renders these adenomas prone to apoplexy. In our study, pituitary apoplexy was significantly more frequent in AIP mutated tumours than in negative cases $(9.5 \%$ vs $3.3 \%, \mathrm{P}=0.001)$; however, this variable did not add any predictive power to the risk model when we adjusted for the other variables.

Gender distribution was statistically significant in the univariate analysis $(61.9 \%$ vs $47.1 \%$ males, $\mathrm{P}=0.001)$, but not when adjusted for the other variables. There is no clear consensus in the published literature about the gender distribution of AIP mutation-positive patients. While several studies reported an increased prevalence of male patients, ascertainment bias probably plays a role, as in large AIP mutation positive families the percentage of affected male patients was lower compared with sporadic AIP mutation-positive cases. $^{8}$

Using the described model, we were able to stratify the risk of AIP mutation into low, moderate and high categories, and we believe this system can be an easy-to-use tool in clinical practice. The model performs well in terms of discrimination, calibration and internal validation. AUC was 0.87 (95\% CI 0.84 to 0.90$)$, where 0.5 represents no discrimination and 1 represents perfect discrimination, indicating that our model achieved an excellent discriminatory power. ${ }^{36}$ Additionally, there were no obvious differences between observed and model-predicted AIP-positive patients. The Hosmer-Lemeshow test showed adequate goodness of fit of our model. ${ }^{36}$ We have validated our model using an internal cross-validation procedure, one of the preferable methods when external validation is not feasible. ${ }^{36}$ The performance of the model was evaluated comparing the explained variation of the model $\left(R^{2}\right)$ in each of the five equal samples of the data and the total sample, achieving a reduction of $R^{2}<10 \%$. $^{36}$ To the best of our knowledge, there is no other available AIP risk category system assessment in the literature for comparison.
Using our risk stratification model, we are able to: (1) describe the risk factors of carrying an AIP mutation; (2) quantify the predictive value for each risk factor adjusted by the others; and (3) estimate the individual risk of carrying an AIP mutation for a given patient. We expect this tool to be valuable for clinicians to improve the decision-making process of referring patients for genetic screening based on the individual risk of AIP mutation.

A screening algorithm based on the results of our risk category system is shown in figure 3 . We need to emphasise that we used age of onset and not age of diagnosis for this analysis. This parameter is often more subjective and needs careful history taking, reviewing parents' height and available photographic evidence of change of features. Patients with pituitary gigantism should be considered to have childhood-onset disease and offered screening.

There are some limitations inherent to our risk model. First, our risk score is based on a cohort enriched with familial, young-onset patients and $\mathrm{GH}$-excess tumours as the number of AIP mutated patients in unselected cohorts is low. ${ }^{937}$ Although all possible diagnostic groups have some representation in our study, caution should be taken when extrapolating these results to a population with significantly different prevalence of AIP mutations than the one found in our cohort; this score ideally estimates the risk in patients where the mutation is already suspected. Second, the determination of age of onset can be subjective and subject to patient recall. Nevertheless, when comparing the model using the age of onset with the one produced using age of diagnosis, the AUC was significantly better using age of onset rather than age at diagnosis; this might be explained due to the well-documented delay of diagnosis in patients with acromegaly. To minimise subjectivity, we categorised the variable age of onset into three broad groups. Finally, it was not possible to perform an external validation of the model due to the relatively low number of cases with $A I P$ mutations in our cohort (although it is the largest AIP mutation positive series so far described), which precluded splitting the sample into a derivation and validation group. However, we have successfully validated the model using an internal cross-validation method.

In summary, the risk category system we have developed has the potential for widespread use as it includes readily available predictors. We believe this tool, ideally used in patients where the mutation is already suspected, can facilitate the most effective use of genetic screening, which we believe is currently clearly underused, allowing the identification of patients who carry AIP mutations and providing the opportunity of early diagnosis in at-risk relatives.

Acknowledgements We acknowledge all patients and their physicians for providing the data for this manuscript. FC has performed this work in the frame of her PhD registered at the Department of Medicine at Universitat Autònoma de Barcelona (UAB).

Collaborators Members of the FIPA consortium are listed at http://www. fipapatients.org/fipaconsortium/.

Contributors FC and MK planned the study. FC, LCH-R, MND, PG and DI collected the data. FC performed the statistical analysis. KS and SE performed the genetic analysis. FC and MK wrote the manuscript. All authors reviewed and approved the manuscript.

Funding FC was supported by a Fellowship of the Fundación Alfonso Martin Escudero. LCH-R was supported by grants from the National Council of Science and Technology and the Secretariat of Public Education from the Mexican Government. DI is supported by a George Alberti Research Training Fellowship funded by Diabetes UK. MK's familial pituitary adenoma studies are supported by the Barts and the London Charity, the Wellcome Trust, the UK's Medical Research Council and Pfizer Ltd.

Competing interests None declared.

Patient consent Obtained.

Ethics approval The Cambridge East Research Ethics Committee. 
Provenance and peer review Not commissioned; externally peer reviewed.

Open Access This is an Open Access article distributed in accordance with the terms of the Creative Commons Attribution (CC BY 4.0) license, which permits others to distribute, remix, adapt and build upon this work, for commercial use, provided the original work is properly cited. See: http://creativecommons.org/licenses/by/4.0/

(c) Article author(s) (or their employer(s) unless otherwise stated in the text of the article) 2018. All rights reserved. No commercial use is permitted unless otherwise expressly granted.

\section{REFERENCES}

1 Ezzat S, Asa SL, Couldwell WT, Barr CE, Dodge WE, Vance ML, McCutcheon IE. The prevalence of pituitary adenomas: a systematic review. Cancer 2004;101:613-9.

2 Fernandez A, Karavitaki N, Wass JAH. Prevalence of pituitary adenomas: a community-based, cross-sectional study in Banbury (Oxfordshire, UK). Clin Endocrinol 2010;72:377-82.

3 Daly AF, Rixhon M, Adam C, Dempegioti A, Tichomirowa MA, Beckers A. High prevalence of pituitary adenomas: a cross-sectional study in the province of Liege, Belgium. J Clin Endocrinol Metab 2006;91:4769-75.

4 Daly AF, Tichomirowa MA, Beckers A. The epidemiology and genetics of pituitary adenomas. Best Pract Res Clin Endocrinol Metab 2009;23:543-54.

5 Vierimaa O, Georgitsi M, Lehtonen R, Vahteristo P, Kokko A, Raitila A, Tuppurainen K, Ebeling TM, Salmela PI, Paschke R, Gündogdu S, De Menis E, Mäkinen MJ, Launonen $\mathrm{V}$, Karhu A, Aaltonen LA. Pituitary adenoma predisposition caused by germline mutations in the AIP gene. Science 2006;312:1228-30.

6 Daly AF, Vanbellinghen JF, Khoo SK, Jaffrain-Rea ML, Naves LA, Guitelman MA, Murat A, Emy P, Gimenez-Roqueplo AP, Tamburrano G, Raverot G, Barlier A, De Herder W, Penfornis A, Ciccarelli E, Estour B, Lecomte P, Gatta B, Chabre O, Sabaté MI, Bertagna X, Garcia Basavilbaso N, Stalldecker G, Colao A, Ferolla P, Wémeau JL, Caron P, Sadoul $J$, Oneto A, Archambeaud F, Calender A, Sinilnikova O, Montañana CF, Cavagnini F, Hana V, Solano A, Delettieres D, Luccio-Camelo DC, Basso A, Rohmer V, Brue T, Bours $V$, Teh BT, Beckers A. Aryl hydrocarbon receptor-interacting protein gene mutations in familial isolated pituitary adenomas: analysis in 73 families. J Clin Endocrinol Metab 2007;92:1891-6.

7 Daly AF, Tichomirowa MA, Petrossians P, Heliövaara E, Jaffrain-Rea ML, Barlier A, Naves LA, Ebeling T, Karhu A, Raappana A, Cazabat L, De Menis E, Montañana CF, Raverot G, Weil RJ, Sane T, Maiter D, Neggers S, Yaneva M, Tabarin A, Verrua E, Eloranta E, Murat A, Vierimaa O, Salmela PI, Emy P, Toledo RA, Sabaté MI, Villa C, Popelier M, Salvatori R, Jennings J, Longás AF, Labarta Aizpún JI, Georgitsi M, Paschke R, Ronchi C, Valimaki M, Saloranta C, De Herder W, Cozzi R, Guitelman M, Magri F, Lagonigro MS, Halaby G, Corman V, Hagelstein MT, Vanbellinghen JF, Barra GB, Gimenez-Roqueplo AP, Cameron FJ, Borson-Chazot F, Holdaway I, Toledo SP, Stalla GK, Spada A, Zacharieva S, Bertherat J, Brue T, Bours V, Chanson P, Aaltonen LA, Beckers A. Clinical characteristics and therapeutic responses in patients with germ-line AIP mutations and pituitary adenomas: an international collaborative study. J Clin Endocrinol Metab 2010;95:E373-83.

8 Hernández-Ramírez LC, Gabrovska P, Dénes J, Stals K, Trivellin G, Tilley D, Ferrau F, Evanson J, Ellard S, Grossman AB, Roncaroli F, Gadelha MR, Korbonits M. International FIPA Consortium. Landscape of familial isolated and young-onset pituitary adenomas: prospective diagnosis in AIP mutation carriers. J Clin Endocrinol Metab 2015;100:E1242-54

9 Cazabat L, Bouligand J, Salenave S, Bernier M, Gaillard S, Parker F, Young J, GuiochonMantel A, Chanson P. Germline AIP mutations in apparently sporadic pituitary adenomas: prevalence in a prospective single-center cohort of 443 patients. J Clin Endocrinol Metab 2012:97:E663-70.

10 Cuny T, Pertuit M, Sahnoun-Fathallah M, Daly A, Occhi G, Odou MF, Tabarin A, Nunes ML, Delemer B, Rohmer V, Desailloud R, Kerlan V, Chabre O, Sadoul JL, Cogne M, Caron P, Cortet-Rudelli C, Lienhardt A, Raingeard I, Guedj AM, Brue T, Beckers A, Weryha G, Enjalbert A, Barlier A. Genetic analysis in young patients with sporadic pituitary macroadenomas: besides AIP don't forget MEN1 genetic analysis. Eur J Endocrinol 2013;168:533-41.

11 Richards S, Aziz N, Bale S, Bick D, Das S, Gastier-Foster J, Grody WW, Hegde M, Lyon E, Spector E, Voelkerding K, Rehm HL. ACMG Laboratory Quality Assurance Committee. Standards and guidelines for the interpretation of sequence variants: a joint consensus recommendation of the American College of Medical Genetics and Genomics and the Association for Molecular Pathology. Genet Med 2015;17:405-23.

12 Korbonits M. Experimental characteristics of mutant AIP proteins. Marseille: ENEA Acromegaly workshop, SY06, 2015.

13 Kasuki L, Vieira Neto L, Wildemberg LE, Colli LM, de Castro M, Takiya CM, Gadelha MR. AlP expression in sporadic somatotropinomas is a predictor of the response to octreotide LAR therapy independent of SSTR2 expression. Endocr Relat Cancer 2012;19:L25-9.

14 Oriola J, Lucas T, Halperin I, Mora M, Perales MJ, Alvarez-Escolá C, Paz deMN, Díaz Soto G, Salinas I, Julián MT, Olaizola I, Bernabeu I, Marazuela M, Puig-Domingo M. Germline mutations of AIP gene in somatotropinomas resistant to somatostatin analogues. Eur J Endocrinol 2013;168:9-13.
15 Williams F, Hunter S, Bradley L, Chahal HS, Storr HL, Akker SA, Kumar AV, Orme SM, Evanson J, Abid N, Morrison PJ, Korbonits M, Atkinson AB. Clinical experience in the screening and management of a large kindred with familial isolated pituitary adenoma due to an aryl hydrocarbon receptor interacting protein (AIP) mutation. J Clin Endocrinol Metab 2014;99:1122-31.

16 Beckers A, Aaltonen LA, Daly AF, Karhu A. Familial isolated pituitary adenomas (FIPA) and the pituitary adenoma predisposition due to mutations in the aryl hydrocarbon receptor interacting protein (AIP) gene. Endocr Rev 2013:34:239-77.

17 Korbonits M, Storr H, Kumar AV. Familial pituitary adenomas - who should be tested for AlP mutations? Clin Endocrinol 2012;77:351-6.

18 Trivellin G, Daly AF, Faucz FR, Yuan B, Rostomyan L, Larco DO, Schernthaner-Reiter MH, Szarek E, Leal LF, Caberg JH, Castermans E, Villa C, Dimopoulos A, Chittiboina P, Xekouki P, Shah N, Metzger D, Lysy PA, Ferrante E, Strebkova N, Mazerkina N, Zatelli MC, Lodish M, Horvath A, de Alexandre RB, Manning AD, Levy I, Keil MF, Sierra ML, Palmeira L, Coppieters W, Georges M, Naves LA, Jamar M, Bours V, Wu TJ, Choong CS, Bertherat J, Chanson P, Kamenický P, Farrell WE, Barlier A, Quezado M, Bjelobaba I, Stojilkovic SS, Wess J, Costanzi S, Liu P, Lupski JR, Beckers A, Stratakis CA. Gigantism and acromegaly due to Xq26 microduplications and GPR101 mutation. N Engl J Med 2014;371:2363-74

19 lacovazzo D, Caswell R, Bunce B, Jose S, Yuan B, Hernández-Ramírez LC, Kapur S, Caimari F, Evanson J, Ferraù F, Dang MN, Gabrovska P, Larkin SJ, Ansorge O, Rodd C, Vance ML, Ramírez-Renteria C, Mercado M, Goldstone AP, Buchfelder M, Burren CP, Gurlek A, Dutta P, Choong CS, Cheetham T, Trivellin G, Stratakis CA, Lopes M-B, Grossman AB, Trouillas J, Lupski JR, Ellard S, Sampson JR, Roncaroli F, Korbonits M. Germline or somatic GPR101 duplication leads to X-linked acrogigantism: a clinicopathological and genetic study. Acta Neuropathol Commun 2016;4:1-12.

20 de Kock L, Sabbaghian N, Plourde F, Srivastava A, Weber E, Bouron-Dal Soglio D, Hamel N, Choi JH, Park SH, Deal CL, Kelsey MM, Dishop MK, Esbenshade A, Kuttesch JF, Jacques TS, Perry A, Leichter H, Maeder P, Brundler MA, Warner J, Neal J, Zacharin M, Korbonits M, Cole T, Traunecker H, McLean TW, Rotondo F, Lepage P, Albrecht S, Horvath E, Kovacs K, Priest JR, Foulkes WD. Pituitary blastoma: a pathognomonic feature of germ-line DICER1 mutations. Acta Neuropathol 2014;128:111-22.

21 Wang K, Li M, Hakonarson H. ANNOVAR: functional annotation of genetic variants from high-throughput sequencing data. Nucleic Acids Res 2010;38:e164.

22 McLaren W, Gil L, Hunt SE, Riat HS, Ritchie GR, Thormann A, Flicek P, Cunningham F. The Ensembl Variant Effect Predictor. Genome Biol 2016;17:122.

23 Domenech J, Navarro J. Command allsets for Stata. Find the best subset for Linear, Logistic and Cox Regression V1.0.7. Bellaterra: Universitat Autonoma de Barcelona, 2014.

24 Katznelson L, Laws ER, Melmed S, Molitch ME, Murad MH, Utz A, Wass JAH. Acromegaly: an endocrine society clinical practice guideline summary of recommendations. J Clin Endocrinol Metab 2014;99:3933-51.

25 Katznelson L, Atkinson JL, Cook DM, Ezzat SZ, Hamrahian AH, Miller KK. American Association of Clinical Endocrinologists. American Association of Clinical Endocrinologists medical guidelines for clinical practice for the diagnosis and treatment of acromegaly--2011 update. Endocr Pract 2011;17(Suppl 4):1-44.

26 Daly AF, Yuan B, Fina F, Caberg JH, Trivellin G, Rostomyan L, de Herder WW, Naves LA, Metzger D, Cuny T, Rabl W, Shah N, Jaffrain-Rea ML, Zatelli MC, Faucz FR, Castermans E, Nanni-Metellus I, Lodish M, Muhammad A, Palmeira L, Potorac I, Mantovani G, Neggers SJ, Klein M, Barlier A, Liu P, Ouafik L, Bours V, Lupski JR, Stratakis CA, Beckers A. Somatic mosaicism underlies $X$-linked acrogigantism syndrome in sporadic male subjects. Endocr Relat Cancer 2016;23:221-33.

27 Lecoq AL, Kamenický P, Guiochon-Mantel A, Chanson P. Genetic mutations in sporadic pituitary adenomas-what to screen for? Nat Rev Endocrinol 2015;11:43-54.

28 Tichomirowa MA, Barlier A, Daly AF, Jaffrain-Rea ML, Ronchi C, Yaneva M, Urban $J$ D, Petrossians P, Elenkova A, Tabarin A, Desailloud R, Maiter D, Schürmeyer T, Cozzi $R$, Theodoropoulou M, Sievers C, Bernabeu I, Naves LA, Chabre O, Montañana CF, Hana V, Halaby G, Delemer B, Aizpún JI, Sonnet E, Longás AF, Hagelstein MT, Caron P, Stalla GK, Bours V, Zacharieva S, Spada A, Brue T, Beckers A. High prevalence of AIP gene mutations following focused screening in young patients with sporadic pituitary macroadenomas. Eur J Endocrinol 2011;165:509-15.

29 Cai F, Zhang YD, Zhao X, Yang YK, Ma SH, Dai CX, Liu XH, Yao Y, Feng M, Wei JJ, Xing B, Jiao YH, Wei ZQ, Yin ZM, Zhang B, Gu F, Wang RZ. Screening for AlP gene mutations in a Han Chinese pituitary adenoma cohort followed by LOH analysis. Eur J Endocrinol 2013;169:867-84.

30 Statement of the American Society of Clinical Oncology. Genetic Testing for Cancer Susceptibility. J Clin Oncol 1996;14:1730-6.

31 Vasilev V, Daly A, Naves L, Zacharieva S, Beckers A. Clinical and genetic aspects of familial isolated pituitary adenomas. Clinics 2012;67(Suppl 1):37-41.

32 Igreja S, Chahal HS, King P, Bolger GB, Srirangalingam U, Guasti L, Chapple JP, Trivellin G, Gueorguiev M, Guegan K, Stals K, Khoo B, Kumar AV, Ellard S, Grossman AB, Korbonits M. International FIPA Consortium. Characterization of aryl hydrocarbon receptor interacting protein (AIP) mutations in familial isolated pituitary adenoma families. Hum Mutat 2010;31:950-60.

33 Leontiou CA, Gueorguiev M, van der Spuy J, Quinton R, Lolli F, Hassan S, Chahal HS, Igreja SC, Jordan S, Rowe J, Stolbrink M, Christian HC, Wray J, Bishop-Bailey D, Berney DM, Wass JA, Popovic V, Ribeiro-Oliveira A, Gadelha MR, Monson JP, Akker SA, Davis JR, Clayton RN, Yoshimoto K, Iwata T, Matsuno A, Eguchi K, Musat M, Flanagan D, Peters G, Bolger GB, Chapple JP, Frohman LA, Grossman AB, Korbonits M. The role 
of the aryl hydrocarbon receptor-interacting protein gene in familial and sporadic pituitary adenomas. J Clin Endocrinol Metab 2008;93:2390-401.

34 Villa C, Lagonigro MS, Magri F, Koziak M, Jaffrain-Rea ML, Brauner R, Bouligand J, Junier MP, Di Rocco F, Sainte-Rose C, Beckers A, Roux FX, Daly AF, Chiovato L. Hyperplasia-adenoma sequence in pituitary tumorigenesis related to aryl hydrocarbon receptor interacting protein gene mutation. Endocr Relat Cancer 2011;18:347-56.

35 Xekouki P, Mastroyiannis SA, Avgeropoulos D, de la Luz Sierra M, Trivellin G, Gourgari EA, Lyssikatos C, Quezado M, Patronas N, Kanaka-Gantenbein C,

Chrousos GP, Stratakis CA. Familial pituitary apoplexy as the only presentation of a novel AIP mutation. Endocr Relat Cancer 2013;20:L11-14.
36 Moons KG, Altman DG, Reitsma JB, loannidis JP, Macaskill P, Steyerberg EW, Vickers AJ, Ransohoff DF, Collins GS. Transparent Reporting of a multivariable prediction model for Individual Prognosis or Diagnosis (TRIPOD): explanation and elaboration. Ann Intern Med 2015;162:W1-73.

37 Preda V, Korbonits M, Cudlip S, Karavitaki N, Grossman AB. Low rate of germline AIP mutations in patients with apparently sporadic pituitary adenomas before the age of 40: a single-centre adult cohort. Eur J Endocrinol 2014;171:659-66.

38 Jarymowycz VA, Cortajarena AL, Regan L, Stone MJ. Comparison of the backbone dynamics of a natural and a consensus designed 3-TPR domain. J Biomol NMR 2008;41:169-78. 